\title{
The takeover of Prague's banking cluster by multinational groups from an evolutionary perspective
}

\author{
JIŘÍ BLAŽEK, ILONA BEČICOVÁ
}

Charles University in Prague, Faculty of Science, Department of Social Geography and Regional Development, Prague, Czechia; e-mail: jiri.blazek@natur.cuni.cz

ABSTRACT This article identifies the main drivers in the evolution of the banking cluster in Prague over the last two centuries. Conceptually, it employs the adaptive-cycle model of cluster evolution, which acknowledges the role of external factors in cluster evolution. An empirical analysis shows that the evolution of the banking cluster in Prague has been primarily driven by several episodes of major external disruptions. A particular attention is paid to the latest phase of cluster evolution, which started around the beginning of the $21^{\text {st }}$ century when Prague's banks were taken over by foreign multinational groups. We argue that, despite the numerous costs and risks associated with this "subsidiarisation" of the banking cluster in Prague, there were benefits, some of which were surprisingly manifested during the 2008-2009 global economic crisis.

KEY WORDS banking cluster evolution - adaptive-cycle model - financial centres - Central and Eastern Europe - global economic crisis

BLAŽEK, J., BEČICOVÁ, I. (2016): The takeover of Prague's banking cluster by multinational groups from an evolutionary perspective. Geografie, 121, 2, 254-278.

Received March 2015, accepted December 2015.

CC Česká geografická společnost, z. s., 2016 


\section{Introduction}

Currently, there is a growing body of literature on the evolution of the global financial centres and their networks (see e.g. Brown, Derudder, Parnreiter 2010; Taylor, Walker, Catalano et al. 2002; Faulconbridge, Engelen, Hoyler 2007; Corpataux, Crevoisier, Theurillat 2009; Wójcik 2009; Martin, Berndt, Klagge et al. 2005) and on what might be called "a new global financial order" characterised by an ever-increasing complexity, interconnectivity, distrust and risks (Lum 2013) and by changes in the global pattern of geo-economic power accompanied inter alia by Asia's rising financial centres (see e.g. Florida 2010). Recent studies have also provided highly interesting insights into the impacts of these global phenomena upon the evolution of the secondary financial centres, e.g. Grote (2008) on Frankfurt; Engelen (2007) and Boschma, Ledder (2010) on Amsterdam; Engelen and Grote (2009) on Amsterdam and Frankfurt; and Zademach and Musil (2014) on Vienna and Munich.

However, an important gap exists in the available literature because so far only minor attention has been paid to the impacts of this new global financial order upon the banking industry in third- or even fourth-tier financial centres, which have never achieved the role of a prominent node of international finance. Research into these financial centres is important as it might enhance understanding of the functioning of the overall global financial system by providing insights into the evolutionary dynamics of lower-tier financial centres and the main drivers. Moreover, these third- or even fourth-tier financial centres are quite numerous, as for example all capital cities of Central and East European Countries would fit into this category. These centres fulfil different functions than the leading financial centres and, therefore, are likely to face different challenges. Consequently, their overall development trajectories as well as the impacts of the global economic crisis are likely to differ from those described in the literature on higher-order financial centres. Yet, in the words of Karreman, "little attention has been directed to rapid (financial) development in Central and Eastern Europe" (Karreman 2009, p. 265).

Nevertheless, the impacts of the global economic crisis upon Eastern Europe and the former Soviet Union have been recently studied by Smith and Swain (2010). These authors forwarded an argument that "geo-economic and geopolitical integration undertaken during their post-socialist transition have contributed to economic vulnerabilities exacerbated by the global crisis", as their dependent market economy model has been "based on internationalisation of the financial sector, cheap credit, and increasing reliance on exports to compensate for energy resource imports" (Smith, Swain 2010, p. 1). Drahokoupil and Myant (2010) have argued equally and identified export demand as a principal vulnerability in Central and East European Countries. However, as far as can be 
determined, no attempt has yet been made to perform a more specific analysis of vulnerabilities, costs and risks resulting from such a development model in the financial sector.

Therefore, the main aim of this article is to analyse the evolution of the banking cluster in one such third-tier city (Prague) in an effort to identify the main internal as well as external drivers of development along its two-centuries-long historical pathway. Special attention is paid to the latest period since the turn of the new millennium, during which the Czech banks were taken over by multinational banking groups, to see what benefits, costs and risks were induced by the "subsidiarisation" process. It needs to be underlined in Czechia, as in Germany, the role of banks within the financial system is much more important than in other, especially Anglo-Saxon, countries, giving rise to a "bank-based system" (Grote 2008, p. 244).

The paper is organised as follows. First, the key theoretical approaches and concepts are discussed. At the end of this section, the research questions of the study are presented, and the third section then explains the methodology employed during the study. In order to identify the main drivers of the evolutionary trajectory, the fourth section starts with a brief overview of the development of the banking sector, and it then presents the main results of the research concerning the benefits, costs and risks stemming from subsidiarisation of this sector in Prague. At the end of this section, the impacts of the global crisis upon Prague's banking sector are also elaborated. Finally, in the conclusion, the key findings are summarised in the context of recent theoretical debate.

\section{Theoretical context: evolution of financial centres from a perspective offered by the adaptive-cycle model of cluster evolution}

Since the 1980s, there has been a rapid growth in the literature on international financial centres with a predominant focus on leading global financial centres such as London and New York and second-tier international financial centres (Zademach, Musil 2014). According to these authors, analysis of the Global Financial Centres Index revealed that "less diversified second-tier financial centres show a lower degree of stability in their competitiveness and are less resilient towards economic cycles that top ranking centres" (Zademach, Musil 2014, p. 464). Importantly, in addition to the strong role of path dependence in the evolution of international financial centres (Grote 2008, Gál 2015), Zademach and Musil (2014) identified two main drivers of current restructuring of second-tier international financial centres - expansion of the private equity industry and corporate takeovers and mergers. These authors concluded their longitudinal analysis of Vienna and Munich by observing a discernible tendency towards greater specialisation 
and diversification among these second-tier international financial centres. In particular, while Munich seems to be gaining an international role for the insurance industry and for private equity, Vienna holds an exceptional position in the financial sector in several countries of Central and Eastern Europe (Zademach, Musil 2014). By contrast, in another recent analysis of the second-tier financial centres of Amsterdam and Frankfurt, Engelen and Grote (2009) concluded that both these centres have recently declined, though by differing pathways - via transnationalisation in the case of Amsterdam and via regionalisation in the case of Frankfurt. In another article, Grote (2008) argued that he expects a lesser role for second-tier financial cities in Europe. This should be, first, a result of the development of sophisticated ICT such as computer-based trading, settlement and paying systems with remote access making location in these centres no longer necessary. Second, in some knowledge-intensive segments such as wealth management, the interactions between customers and banks are increasing in importance, as physical proximity enabling face-to-face contact is regarded as a competitive advantage, which leads to the dispersion of banking activity far below these second-tier international financial centres (Grote 2008).

In contrast to the considerable attention that has recently been paid to the highest strata of the hierarchy of the global financial centres, only limited attention has been paid to the evolution of financial centres in peripheral or emerging economies (Karreman 2009, Gál 2015). According to Gál, the financial centres in Central and Eastern Europe are typical by their extreme external dependency as command and control functions over Central and Eastern Europe subsidiaries rest within the West European international financial centres network. Namely, Central and Eastern Europe financial centres are organised around three main city clusters: "a south-east cluster controlled by Athens, a central-east cluster controlled by Vienna and a Baltic cluster controlled by both Copenhagen and Stockholm" (Karreman 2009, p. 260).

As a consequence of this external dependence, evolutionary pathways of the Central and Eastern Europe financial centres are likely to differ from those of higher-rank international financial centres (Gál 2015). Gál identified two main processes transforming Central and Eastern Europe capital cities into financial centres. First, metropolitan transformation, which has led to deep economic restructuring, including a profound shift from industrial to service economy. Second, the international integration of these capitals into the world-city network, which has played a key role in the formation of international financial centres functions in these capital cities (Gál 2015). Nevertheless, Gál concludes that the high external dependency of these capitals prevents the development of fullyfledged financial-centre functions; however, in the best cases careful economic policies within these countries can help to develop certain international financial centres functions in their capitals (Gál 2015). 
Despite the widely recognised tendency of financial actors to concentrate geographically in prominent nodes (cfr. Cassis 2010), the number of studies that have explicitly applied the cluster concept in the analysis of the evolution of the banking sector is limited. This is surprising, as banks also fulfil the second key element of Porter's definition of cluster, i.e. the existence of links of a competitive and cooperative nature among the members of a cluster (examples of the latter include sharing online paying systems and networks of cash dispensers, running joint-bank registers of clients, provision of syndicated loans, joint lobbying, etc.). Moreover, Porter himself explicitly forwarded the case of financial services in New York as an example of cluster (Porter 2003, p. 562). An important exception is Boschma and Ledder's (2010) longitudinal survival analysis of banks clustered in Amsterdam.

In addition, from an evolutionary perspective, the banking cluster represents an interesting example, as it epitomises a strong case of a cluster that maintains its identity even over large timespans due to the distinctive role of the banks within the economy.

Theoretically, this paper is based upon the evolutionary approach to the research of banking clusters with special attention to the adaptive-cycle model with its specific evolutionary trajectories, as recently proposed by Martin and Sunley (2011). The adaptive-cycle model is a result of the efforts to develop the understanding of the evolution of complex socioeconomic systems such as clusters beyond the rather prescriptive implications of the more established cluster-lifecycle model (see Menzel, Fornahl 2010). According to Martin and Sunley (2011, p. 1306), the adaptive-cycle model "was initially developed to describe the evolutionary dynamics of ecological systems but has since been applied more widely in ecological economics and social-ecological studies". These authors argue that the adaptivecycle model represents an advance over the traditional lifecycle model, because (i) it represents a meta-model stressing the role of a continuous dynamic process, but the model does not expect a predetermined pathway of development - on the contrary, the authors expect significant variation and unpredictability of evolutionary trajectories inter alia due to intensive cross-scale interactions, (ii) it foregrounds the importance of the recombination and reuse of resources, and therefore the adaptive-cycle model stresses both path- and place-dependence, (iii) the dominant role of downward causation effects (i.e. from cluster to firms) presupposed by the lifecycle model is questioned, and the adaptive-cycle model instead tries to capture both upward and downward causation, and (iv) it allows greater scope for the critical influence of a contingent agency (Martin, Sunley 2011, pp. 1308-1312).

Therefore, the main argument of the adaptive-cycle model is that it is hardly possible to identify a dominant dynamic responsible for driving the evolution of the cluster into different phases over the period investigated (Martin, Sunley 
2011). Consequently, Martin and Sunley (2011, p. 1312) proposed a set of six courses of possible evolutionary trajectories of clusters, reflecting the fact that "there are numerous development trajectories whose realisation depends on contingent and strategic decision-making by cluster-based firms".

In particular, the authors proposed the following six alternative evolutionary trajectories under the adaptive-cycle model: cluster full-adaptive cycle (characterised by the sequence of emergence, growth, maturation, decline and replacement by a new cluster), constant cluster mutation (emergence, growth and constant structural and technological change), cluster stabilisation (emergence, growth, maturation, followed by stabilisation), cluster reorientation (upon reaching maturation, firms reorient their specialisms and new clusters emerge), cluster failure (in the case of emergent clusters) and cluster disappearance (after emergence, growth, maturation and decline). Moreover, the authors explicitly acknowledge an inevitable existence of hybrids and combinations among the six different evolutionary trajectories. Therefore, the adaptive-cycle model "explicitly rejects a single, cumulative and imminent logic determining system evolution and instead emphasises that system change is an outcome of the balance between experimentation and novelty, and conservation and selection, as well as the interactions between entities at different scales" (Martin, Sunley 2011, p. 1309). The emphasis upon the role of interactions between entities at different scales is of particular relevance to the banking industry not only due to the generally acknowledged high level of globalisation in the current financial system, but also due to the unique powers of the regulators (such as central banks).

On the other hand, again according to Martin and Sunley (2011), the basic weakness of the adaptive-cycle model is the fact that it does not elaborate on the detailed process driving the evolution. In addition, Boschma and Fornahl (2011, p. 1296) have coined the following critique of the adaptive-cycle model: "The adaptive cycle model may do more justice to the complexity of the context-specific evolution of clusters, but it also runs the risk of coming up with as many trajectories of clusters as there are clusters. The cluster lifecycle approach is stronger in searching for general drivers of cluster evolution, and is better capable of deriving testable hypotheses concerning the circumstances under which particular cluster trajectories emerge."

Nevertheless, the adaptive-cycle model appears to be conceptually more balanced, as it provides a wider space for the incorporation of both internal and external drivers of development, whereas the cluster-lifecycle model, despite acknowledging interactions of clusters and their members with the external context, seems to focus especially on internal factors such as heterogeneity of knowledge as the main drivers of development (Menzel, Fornahl 2010). However, these two models should not be considered as contradictory or even mutually exclusive, but the adaptive-cycle model should be perceived rather as a model that advances 
the insights developed by the cluster-lifecycle model concerning the evolution of complex socioeconomic systems such as clusters. Therefore, the adaptive-cycle model should be regarded as a welcome extension of the more established clusterlifecycle model.

Accordingly, Boschma and Fornahl (2011) call for an investigation of the internal and external processes that are responsible for the transition of the cluster between stages. Boschma and Fornahl also argue that more efforts are needed in performing longitudinal studies on clusters, despite the obvious data limitations of such studies. Consequently, two main research questions have been formulated: (i) What were the main internal and external drivers of the evolution of the banking cluster in Prague, and is it possible to identify a dominant dynamic responsible for driving the evolution of the cluster into different phases over the period investigated? (ii) Would any of the six evolutionary trajectories of the adaptive-cycle model fit the evolution of the banking cluster in Prague?

\section{Methodology}

From a methodological point of view - given the nature of the research - qualitative methods were employed during the course of this study. First, desk research was carried out on existing materials ranging from reports from the Czech or Czechoslovak National Bank to an opus magnum on the historical trajectory of banking in Czechia by Vencovský, Jindra, Novotný (1999).

Second, 22 in-depth semi-structured interviews with a spectrum of banking and financial experts were performed over a 17-month period (March 2012 - July 2013). The main aim of the interviews was to obtain a detailed account of the drivers of change in Prague's banking sector, ${ }^{1}$ and especially to investigate the changes induced by the takeover of Czech banks by the multinational banking groups. The experts were selected in such a way as to obtain insights about the evolution of the banking cluster from various perspectives. Therefore, the spectrum of experts interviewed ranged from the CEO who ran one of the leading Czech banks after its takeover by a transnational banking group, via experts occupying various managerial positions in banks, to bankers from the Czech National Bank. Given the strong dominance of the three leading banking houses in Prague's banking cluster, an effort was made to interview at least three experts from each of these banks to provide a more balanced picture. This strategy proved particularly

1 The control functions (i.e. the banks' headquarters) of the Czech banking sector have been strongly concentrated in Prague over the whole period investigated. Moreover, in several periods - including the current one - all headquarters of the banks were located in Prague. Therefore, reference to Prague's banking cluster is considered justified. 
useful, as different insights were obtained in some cases. In such instances, a second round of interviews was performed with the experts concerned to clarify the controversial issues.

Moreover, to obtain a more balanced view on the evolution of the banking cluster, six experts working in non-banking financial institutions were also interviewed. The interviews addressed the following main topics: (i) identification of internal and external drivers of evolution in the banking sector, (ii) changes introduced by foreign banking groups after the takeover of Czech banks, (iii) perceived benefits, costs and risks stemming from the subsidiarisation of Prague's banking cluster, and (iv) the impacts of the global economic crisis on the banking cluster in Prague.

Due to the dominant role of the banks and Prague within the Czech financial sector, the study focuses on Prague's banking cluster, and reference to other financial institutions is made only when relevant for the purpose of this study.

\section{Ups and downs in the evolution of Prague's banking cluster}

The aim of this historical framework is to scrutinise the evolutionary dynamics of Prague's banking cluster to see if it is possible to identify a dominant dynamic driving the evolution of the cluster over the period investigated. Therefore, particular effort is made to identify the main internal and external drivers of change, which would determine the relevance of the adaptive-cycle model and its various evolutionary trajectories for the case of Prague's banking cluster. Consequently, a brief outline of the turbulent history of the Czech banking sector is provided (phases 1-3), followed by an analysis of the recent transformation of the banking cluster in Prague (phase 4 and especially phase 5).

\subsection{Emergence of a banking cluster in Prague (from early $19^{\text {th }}$ century to 1918)}

Modern Czech banking evolved gradually during the second half of the $19^{\text {th }}$ century. Previously, in the early $19^{\text {th }}$ century, the banking sector in Czechia consisted mostly of a network of very small financial institutions, specifically several types of savings banks. Given the current state of affairs in the global financial sector, it is necessary to emphasise that the savings banks were established in the late $18^{\text {th }}$ century and early $19^{\text {th }}$ century as philanthropic or even charitable institutions. ${ }^{2}$

2 This was also a rationale for establishing the Erste Oesterreichische Spar-Case (in Vienna, in 1819), which was a direct predecessor of the Erste Bank - nowadays a leading bank in Czechia and in several other Central and East European Countries. 
In those days, savings banks motivated thriftiness among poor people by providing 3-4 percent interest and thus encouraged them to form a reserve to cushion them against possible periods of hardship in life, such as unemployment or illness. Therefore, savings banks were originally not designed for the provision of loans.

In addition, about 3,700 Raiffeisen-type savings banks (called "kampelička" by Czechs) were established in rural areas mostly based on a municipal principle. However, none of these institutions was able to provide credits for larger projects such as the construction of infrastructure or industrial plants. This was a severe constraint, because at that time the Central Austro-Hungarian Bank discriminated against Czechia. According to Vencovský, Jindra, Novotný (1999), for example in 1870 , the share of credits provided by this bank to Czechia was less than $7 \%$, which was at odds with the strongly industrial character of this part of the AustroHungarian Empire.

Therefore, the establishment of the "Land Bank of the Czech Kingdom" (Zemská banka království českého) was proposed by the emerging (zech political elite. The Land Bank was established in Prague on the basis of a joint platform formed by the small Czech savings banks in 1890. The main aim was quite straightforward: the provision of cheap credit for the construction of required infrastructure (regional railways, water pipelines, bridges, and schools, but also credits for the construction of industrial plants). Moreover, the Land Bank played a key role in the establishment of several other banks. Therefore, the establishment of the large Land Bank of the Czech Kingdom was an important component of the economic emancipation of the Czechs in the second half of the $19^{\text {th }}$ century. Strongly growing Czech capital even started to expand via various forms (such as setting up industrial plants, credit provision for mining, setting up subsidiary banks, etc.) abroad, especially in South-East Europe (Vencovský, Jindra, Novotný 1999).

From a theoretical point of view, a combination of internal and external drivers has been identified for this phase of the emerging banking sector. Specifically, the main drivers of change were the association of Czech small saving banks and the emerging political elite of the Czech nation.

\subsection{Expansion of the banking sector after the establishment of Czechoslovakia} (1918-1939)

A strong impetus for the development of the banking sector in Czechia was provided by the establishment of an independent Czechoslovak state as a result of WWI. Therefore, the main driving force during the second period in between the two world wars was the overall political and economic transformation following the creation of the new state. Banks played a key role in the reconversion of industrial production to peace-time production and also later in the establishment 
of new industries that were missing in Czechoslovakia at that time (production of aeroplanes, electro-technics, explosives, etc.). Moreover, banks became important traders in basic goods such as coal, cotton and sugar. Despite several banking crises that occurred between the two world wars, the Czechoslovak banking sector developed considerably during that period (Mervart 1998).

\subsection{Passive banking under state socialism (1948-1989)}

After WWII, the Czech banking sector had no time to recover from all sorts of devastation caused during the war, as the communists became a dominant political force and a few years later (in February 1948) gained unlimited power. The banking sector was fully nationalised shortly after the war, and in 1950 it was centralised into a state "mono-bank" fulfilling the functions of both a central bank and commercial banks. More importantly, the state "mono-bank" and a few of its only formally independent satellite banks were transformed into a sort of cash dispenser operating according to the state plan approved by the politbyro of the Communist Party. Therefore, the "state directed the distribution of funds throughout the economy without taking their productive use into account" (Weill 2003, pp. 571-572). Moreover, the banking services were severely limited both in terms of their range (e.g. no mortgages were available to Czech households under state socialism) and in terms of their number (due to the limited number of economic subjects in the country, as the centrally planned economy consisted mostly of state-owned monopolistic enterprises). Unsurprisingly, the Prague stock exchange was abolished altogether as the stock market was considered to be an "iconic" symbol of capitalism.

Therefore, an exogenous driver, namely the imposition of the central planning system that led to the marginalisation of the banking sector's role under state socialism from the early 1950 s, can be seen as the fundamental driver of evolution in this phase.

\subsection{Revival of the banking sector and two banking crises (1990-1999)}

Political and economic transformation after the collapse of state socialism induced fundamental changes within the banking sector. One of the first steps after the 1989 Czechoslovak "velvet revolution" was the re-establishment of a classical twotier banking system by splitting the State Bank of Czechoslovakia into the central bank and four commercial banks. In addition, to meet the surging demand for banking services induced especially by a rapidly growing private sector and by the liberalisation of foreign trade, the central bank started to issue banking licences 
to new - usually small - banks established by emerging Czech financial groups. Consequently, the number of banks increased dramatically (in 1993, there were already 52 banks).

Interestingly, several of these newly established banks used the name of the banks that existed prior to World War II. The names (and sometimes even the business model, such as the market segment) of the former banks were "borrowed" by new owners to invoke tradition, reputation and credibility. Therefore, despite a long gap of approximately 50 years in the operation of banks according to market principles, elements of path dependence could be identified.

However, according to Hrnčír (1994), the emerging banking sector suffered from several deficiencies. First, a low standard of banking services from the previous period persisted; second, the range of products offered to clients was extended only gradually; and third, the banks were suffering from high operating costs and from overstaffing due to a low level of automation. Consequently, the main source of banks' profits was a wide spread (5-7 percentage points) between the banks' borrowing and lending interest rates facilitated by low competitive pressure (Hrnčír 1994).

Moreover, substantial problems soon emerged in the banking sector due to a combination of the following main factors. First, risk management was clearly underdeveloped for both objective and subjective reasons. Objectively, a huge majority of private firms had been newly established, so they had no history and, consequently, the standard approaches of risk management during the credit allocation procedure could not be applied. Subjectively, in those days the volume of loans provided or the market share mattered most to bank managers, not the solvency of the clients. Second, there was little experience with the principles of the market economy both on the side of banks (many newly hired employees and even managers had no banking experience whatsoever) and among new entrepreneurs, while the economy underwent deep "transformation recession" induced by both external and internal shocks (i.e. sudden openness to foreign competition and fundamentally changed rules of operation for the economy after the application of shock therapy in January 1991). In addition, inexperience of the banking staff was often combined with fraudulent behaviour by bank owners and managers (Bárta, Singer 2006). Third, a heavy burden, especially for the large banks established by splitting the former state mono-bank, comprised the heritage of non-performing loans provided during the period of state socialism to the former state companies. Consequently, debt-contract failures became a mass phenomenon (Hrnčír 1994). According to the same author, these large banks were all technically bankrupt (Hrnčír 1994). Fourth, the banks were clearly undercapitalised (Bárta, Singer 2006).

Importantly, all these deficiencies were multiplied by a weak legal framework. Therefore, extensive business groups swiftly emerged (often based on the 
networks built under state socialism among illegal traders with hard currency and with other shortage goods), pursuing semi-legal business practices. In illustration of this non-interventionist "hands-off" approach of that period in Czechoslovak government, the following confession is highly illuminating. In 2013, one of the former economic ministers admitted that in 1990 a discussion took place among senior public officials on whether the capital market should remain without supervision for a period of one or two years to allow for the "needed accumulation of capital" (Ježek 2013).

Moreover, there was strong political pressure on the banking sector, as the prime minister was urging banks "to take-up the risks" in order to facilitate the privatisation process. Needless to say, at that time the largest banks were still predominantly state-owned. Therefore, the provision of non-standard loans was considered "normal". Unsurprisingly, in the second half of the 1990s this approach resulted in two banking crises, creating a vast burden upon public finances, which had to save this ill-founded banking sector. Some small banks were merged with other banks, while other banks ceased to exist altogether.

Consequently, it became obvious that even the large banks would not survive without radical measures. Moreover, Czechia had been preparing for membership of the EU and was therefore getting ready for implementation of the acquis communautaire. Therefore, the balance sheets of these banks were firstly cleaned up by injection of a substantial amount of public money and, subsequently, the banks were sold to foreign investors. A majority of shares in the Československá obchodní banka were bought by the Belgian KBC Group in 1999, the Czech Savings Bank (Česká spořitelna) was sold to the Austrian Erste Bank in 2000, and finally, the Komerční banka was taken over by the French Société Générale in 2001.

Accordingly, no single, most important driver can be identified for the revival period of the banking cluster after the collapse of state socialism. Instead, a combination of the overall political and socioeconomic transformation devised by the government and of "sharks" operating within the poorly regulated banking sector comprised the main drivers of evolution.

\subsection{Phase of "subsidiarisation" after the takeover by foreign investors (2000-)}

The takeover of Prague's banking sector by foreign banking groups undoubtedly represented a fundamental shift in the development trajectory of this banking cluster. However, while the basic reason for a shift in evolutionary trajectory was the malfunctioning of the banking cluster, i.e. the internal dynamic, the basic impetus for change came from the Czech government and from the Czech National Bank, which were frustrated by the underperformance of the banking sector. Consequently, to remedy the generally unsatisfactory situation, foreign banking 
groups were invited in. Conceptually, this evolutionary dynamic is illuminating as it broadens the spectrum of possible mechanisms, eventually leading to a "second wind" scenario after a major shock (as proposed by Martin, Sunley 2011), resulting in the upgrading of products, greater productivity and increased competitiveness of cluster firms.

The takeover of Prague's banks by foreign banking groups, which was completed in 2001, is generally evaluated favourably on the basis of their substantially improved overall performance and introduction of new services (e.g. Bárta, Singer 2006; Klein 2012), despite the fact that the banks were transformed into mere subsidiaries of foreign banks. However, it should also be emphasised that the consolidation of the Czech banks orchestrated by the new owners was undoubtedly facilitated by a period of strong economic growth achieved during the years from 2000 to 2007 (see Table 1).

The takeover of the Czech banks was assessed as inevitable by the experts interviewed, as the banks were technically bankrupt and radical change in their operations was urgently needed. There was general agreement among the experts that the impacts of the takeover of the Czech banks by foreign capital were profound and multifaceted. Consequently, various benefits, costs and risks stemming from the takeover and subsequent subsidiarisation were identified during the interviews.

\section{Benefits}

First, the experts argued that the general creditworthiness of the banking sector among the population has increased, which helped to avoid any form of panic amongst the wider public in relation to their bank deposits. Moreover, new managerial and organisational structures and procedures have been introduced, enhancing the overall stability of the sector and resulting inter alia in a radical decrease in the number of non-performing loans (see Fig. 1). Even more importantly, the overall volume of credit continued (with some fluctuation) to grow. The increase in credit and decrease in non-performing loans contrast with the expectations derived from the dependent model of internationalisation of Central and East European Countries (see Smith, Swain 2010). The most likely explanatory factor for this exception is a favourable deposit-loan ratio, which is typical for Czechia.

Typically, sound risk management procedures have been established (in both credit allocation and operations on the inter-bank market). Moreover, these new procedures have been accompanied by the introduction of a new incentive system for employees, one that rewards customer satisfaction and viable loans. On the other hand, a tracking system that holds employees accountable for their actions has also been introduced (Klein 2012). In addition, the integration of the Czech 


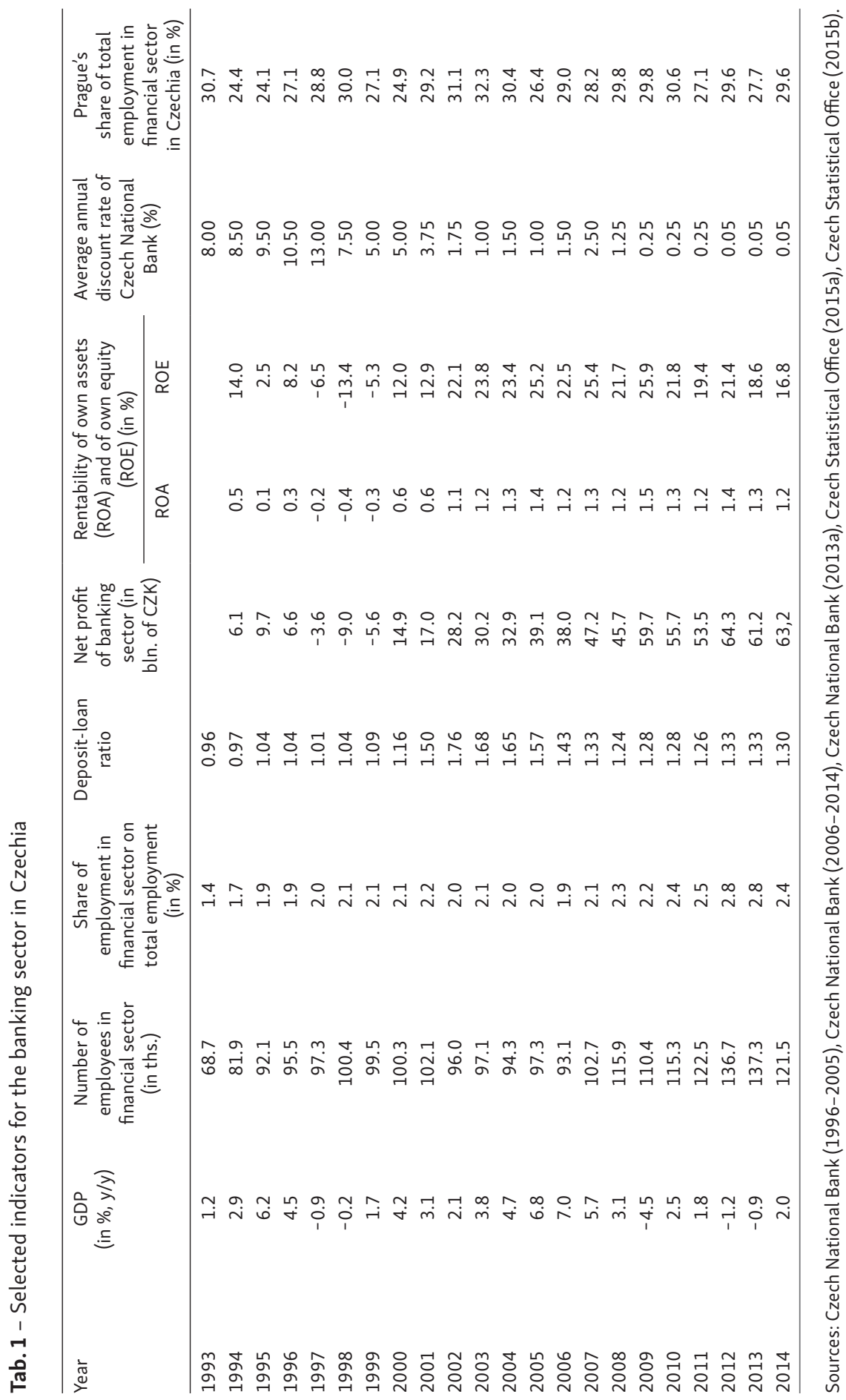




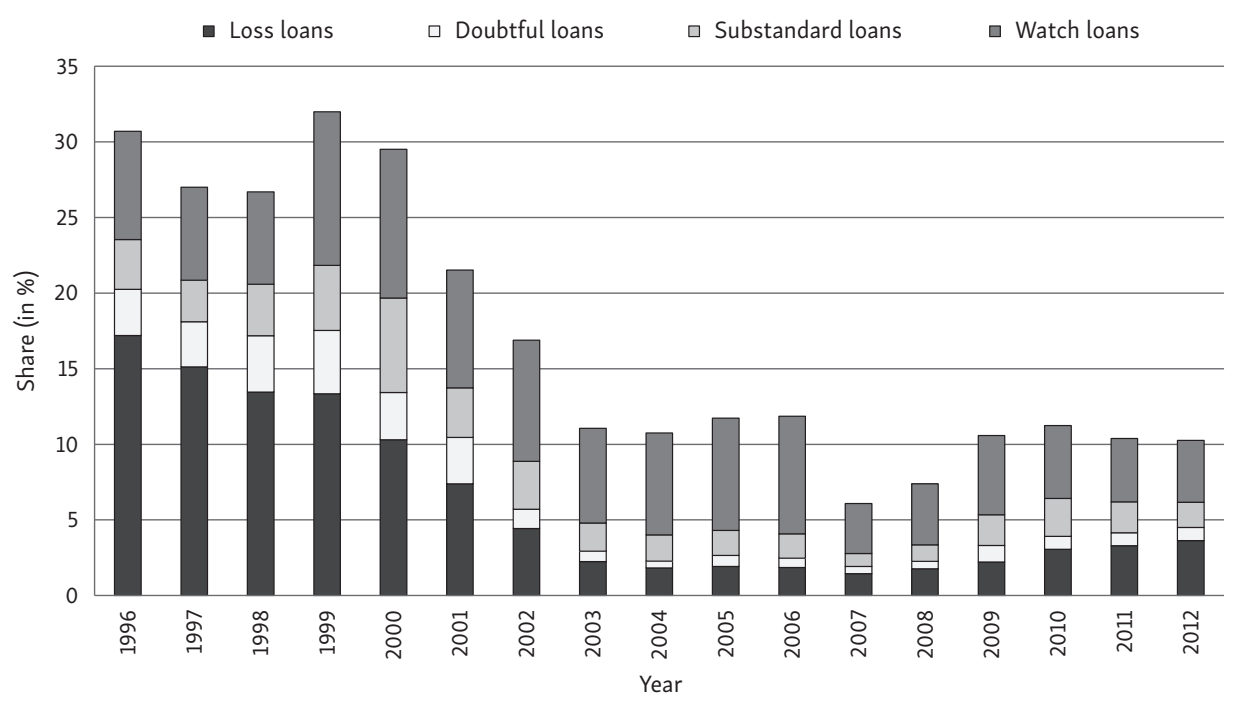

Fig. 1 - The share of non-performing loans in total volume of disbursed credits. Source: Czech National Bank (1994-2013).

banks into foreign banking groups enhanced their ability to adapt to changes, for example to new regulations concerning money-laundering that required sophisticated systems. The other side of the coin is obvious: the subsidiaries had to pay heavily for these new systems.

Moreover, international standards have been brought in with regard to transparency in the book-keeping system and accounting. A range of new and quality services for various types of clients has also been introduced, facilitated by a substantial transfer of know-how from the parent banks. In addition to The Erste, KBC and Société Générale, experts stressed the role of know-how injected by American Citibank and GE Money Bank, which commanded the most automated and sophisticated IT systems.

The privatisation of the banks also helped to introduce a truly competitive environment within the banking sector, as during the 1990s the leading banks continued to concentrate their activities upon the segment that they served within the "mono-bank" system under state socialism. By contrast, after the takeover, the leading banks' move towards the provision of universal banking services was deeply pronounced. Counter-intuitively, the loan-to-deposit ratio also increased significantly, which allowed provision of more loans to the Czech economy. However, and closely related to previous point, whereas the volume of loans provided to households has increased massively, this is not the case with corporate loans (see Fig. 2). Two main factors can help to explain this particular form of credit boom. First, on the supply side, foreign owners of the Czech subsidiaries spotted 


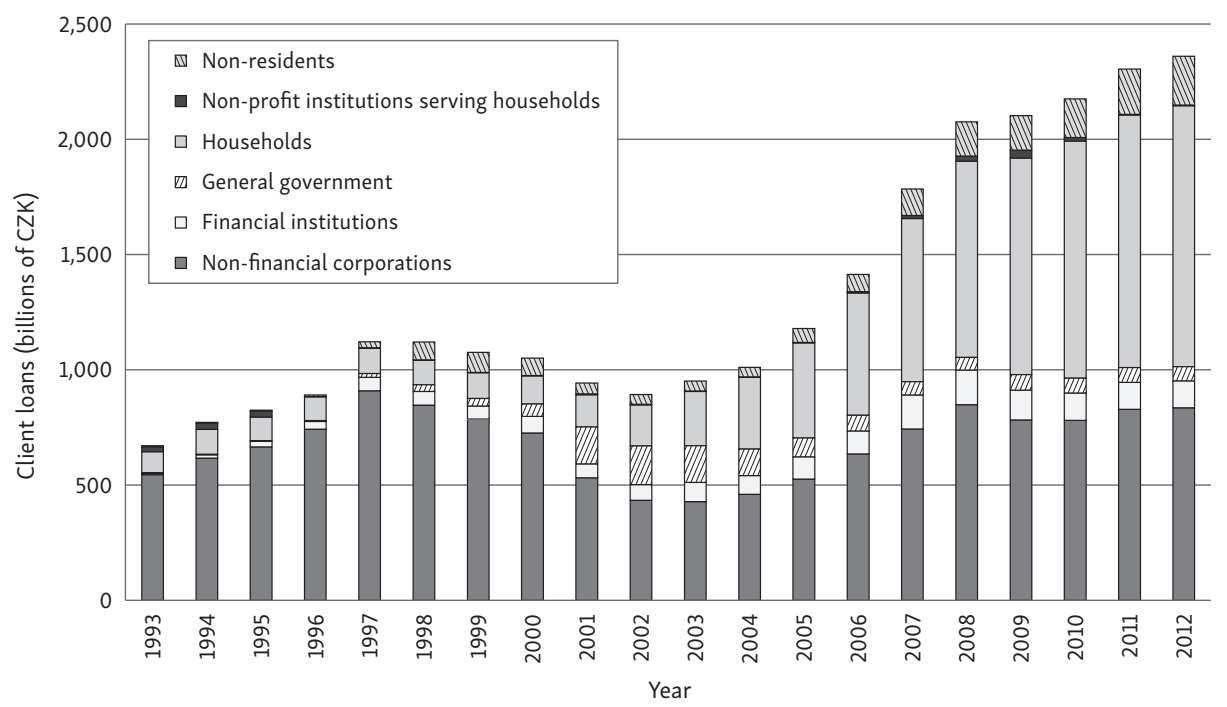

Fig. 2 - Evolution of the structure of loans disbursed. The data relate to 31 December. The values display sums of CZK and foreign currencies. Source: Czech National Bank (2013a, b).

the vast potential in the provision of various sorts of loans to households, as the ratio of these loans to GDP was not only much lower than is common in the most developed countries, but even significantly lower than in Hungary and, especially, Poland (Gál 2015). Second, on the demand side, the rapid economic growth in the pre-crisis period resulted in a large demand for new housing, which was often financed via mortgages.

Finally, and perhaps most importantly, a type of ethical code for bankers has been enforced, which crucially resulted in isolating the banks from political influence.

\section{Costs and risks of subsidiarisation}

On the other hand, some experts expressed concern about the dominant position of the foreign banking groups within the Czech banking sector. Their concerns can be summarised by the following trinity: employment, money and power. While the effects upon employment are seemingly quite straightforward (cfr. for example Engelen 2007), the existing data have so far not yet supported the expected general trend of downsizing employment in the Czech financial sector. Nevertheless, new management in several Czech subsidiaries decided to relocate some back-office functions (such as some of ICT services or human resource management) out of Prague to economise on costs and to cope with the labour shortage in the overheated labour market in Prague at that time. 
Several sorts of financial mechanisms representing the "cost of subsidiarisation" were identified by the experts. While the most visible channel for profits outflow for the wider public is the outflow of banks' dividends from Czechia to their foreign shareholders, there are also more sophisticated - and therefore less obvious - mechanisms for profits-channelling. For example, the Czech Central Bank is following the mutual trade with various equities between "parents" and their Czech subsidiaries to ensure that the cost of these instruments is not overpriced. Moreover, some experts observed a tendency to reassign some of the most profitable banking services (such as corporate banking) directly to the parents' headquarters. Unfortunately, there are no data available to quantify the scale of such transfers. Nevertheless, according to some interviewees, the financial volume of these operations could easily surpass the volume of direct dividend transfers.

Particular cases of negative impacts stemming from the loss of autonomy (power) are difficult to pinpoint. Nevertheless, interviewees observed a change of investment strategy in various types of mutual funds owned by the banking groups towards higher internationalisation or even a complete transfer of asset management of these funds into higher-order financial centres by mergers and acquisitions. A similar observation was recently made even for a second-tier city (Amsterdam) by Engelen and Grote (2009). Likewise, still greater pressure upon the underperforming Prague stock exchange (in contrast to the Warsaw stock exchange, for example) can be expected, as foreign banking groups are unlikely to trade heavily in the local stock market. Consequently, an alternative route for Czech firms to obtain external capital through equity (in contrast to bank's credits) is gradually disappearing.

In addition, the potential for expansion of subsidiaries' activities abroad is limited, or even impossible, in cases where the parent company has another subsidiary already operating in this territory.

Interestingly, one of the interviewed central bankers argued that in his opinion the takeover of Czech banks has a smaller negative impact on the Czech economy than the takeover of a sizeable part of the Czech manufacturing industry by foreign owners and the locking-in of Czech medium-sized firms to the lowest tiers of the global production networks. In the same vein, one expert argued that, in contrast to manufacturing activities, which can be relatively easily relocated, delocalisation of basic banking services is unlikely, as their provision is closely tied to the local environment.

Consequently, the overall effect of the takeover of the Czech banks by foreign banking groups was assessed favourably, and several experts explicitly talked about "radical improvement". 


\subsection{Impacts of the global economic crisis upon the banking cluster in Prague}

In the literature, there are two contrasting views upon the nature of the global economic crisis in Central and Eastern Europe, emphasising either the external nature of the crisis or internal vulnerabilities revealed by the crisis (Gál 2015). However, probably the most reasonable stand on this issue is the one taken by Smith and Swain (2010), who argue that the crisis is as much internal to the region as it is an adjustment to an external shock. In particular, these authors argue that "the crisis has to be understood within the context, first, of a particular model of development wedded to the internalization of the financial sector and cheap credit in the region, and second, to the internalization and increasing dependency on export markets" (Smith, Swain 2010, p. 3). From this position inter alia follows a high probability of differing impacts of the crisis upon particular countries emanating from the different nature and scale of their internal imbalances and vulnerabilities.

Despite the fact that one would intuitively expect that important changes would have occurred in Czechia as a consequence of the global economic crisis, the interviews surprisingly indicated no profound changes in Prague's banking sector during the crisis. Likewise, Gál recently argued that the financial and economic crisis had a "moderate impact on Prague's banking sector as the banking market was prudent, and the share of foreign currency loans ... was insignificant" (Gál 2015, p. 74). This is also in accordance with data in Table 1, which show that the Czech banking sector remained profitable even after the onset of the global economic crisis in Czechia in 2008.

According to the interviewees, there are two main reasons for such a moderate impact of the crisis. First, the balance sheets of the banks were cleared thoroughly during the privatisation process, and, moreover, as a result of the introduction of sound risk-management systems, the crediting of poorly performing (often still semi-state) firms has been stopped. At the same time, the overall social and economic impacts were cushioned by the fact that this change was implemented during a period of robust economic growth (2000-2007). Second, an important factor for the relatively minor impacts of the global economic crisis is that Czech subsidiaries were not involved in trading with obscure financial derivatives ("toxic assets") or in other forms of risky business. This is not to say that the parents banned their Czech subsidiaries from dealing with these types of assets, but, rather, that it was a result of their specialisation within the multinational group primarily to serve local/national markets. In addition, balanced loan-to-deposit ratios provided enough internal savings for lending and made the provision of parent-bank funds unnecessary, while low interest rates on borrowing (related to Czech National Bank policy of low interest rates) helped to avoid the foreign currency denominated lending that led to severe problems in several Central and Eastern Europe countries (Hungary, The Baltics). 
Therefore, the banking cluster in Prague was hit only indirectly by the global crisis via, first, a general quelling of economic activity in the country resulting from declining external and subsequently also domestic demand, and second, the increased pressure upon the parent banks stemming from their wider exposure to various sorts of risks and losses connected with the global economic crisis. Due to the fact that the Czech subsidiaries used to generate the lion's share of profits in some of the foreign banking groups to which they belong, the Czech subsidiaries have recently been squeezed significantly by their parents. In particular, the Czech subsidiaries are now expected to continue to generate above-standard rates of profit for their shareholders, which is increasingly difficult due to growing competition within the sector (see below).

Moreover, the relatively high rate of profit has been achieved as a result of three main factors: (i) generally high fees for various services, (ii) generally high spread of interest rates, and (iii) the good quality of the banks' portfolios. However, whereas the interest rates on loans are gradually falling, the banks came under considerable pressure from the public over the fees that they charge. Consequently, in a situation when the revenue side of the banks' balance sheets is stagnating and facing serious challenges, radical measures are being enforced on the expenditure side. Therefore, despite the continuing profitability of the Czech banking sector, managers have been forced to embark upon a course of strict economising, which includes significant labour-shedding. Nevertheless, despite these indirect negative effects, Prague's banking cluster has to a large extent been shielded against the worst impacts of the global economic crisis due to its predominant orientation towards the Czech market.

Therefore, moderate impacts of the global economic crisis upon the banking cluster in Prague are supported by the observations of Gál, who insists that the crisis resulted in differentiation of development paths not only at the level of particular Central and East European countries, but also at the level of their capital cities including their position in the global financial system (Gál 2015).

\section{Conclusions}

At the conceptual level, three main conclusions can be drawn. First, and most importantly, this study supports the main argument of the adaptive-cycle model that it is hardly possible to identify a dominant dynamic responsible for driving the evolution of the cluster into different phases over the period investigated (Martin, Sunley 2011). Instead, different internal and external drivers of cluster evolution have been identified (though the latter ones seem to prevail - see Table 1).

Second, when looking back over the turbulent evolution of the Prague banking cluster over the last two centuries, from the set of cluster evolutionary trajectories 
proposed by Martin and Sunley (2011), the closest evolutionary trajectory seems to be the "constant cluster mutation" pathway. However, while the adaptive-cycle model of cluster evolution has been developed to conceptualise the evolution of complex socioeconomic systems under the conditions of a relatively stable institutional framework of capitalist societies, occasional major shocks are acknowledged (see Martin, Sunley 2011). By contrast, the evolution of the banking cluster in Prague was - alongside the more-or-less constant mutation - driven primarily by several episodes of major disruption of an exogenous nature. These major disruptions were WWI and the subsequent creation of an independent Czechoslovakia in 1918, WWII and the subsequent period of more than 40 years of state socialism, the reintroduction of the market economy in the early 1990s, and lastly the takeover of Prague's banks by multinationals at the turn of the new millennium. Importantly, in the case of the evolution of Prague's banking cluster, at least some of these episodic disruptions represented the major driving force of evolution per se (with both positive and negative connotations).

Third, the investigation of the evolution of the banking cluster in Prague showed that, despite the fact that five phases had been identified during two centuries in the evolution of this cluster, in several cases it proved cumbersome to equate an actual phase with one of the pre-given phases of the adaptive-cycle model. For example, in the revival period following the collapse of state socialism, the banking sector expanded rapidly according to the quantitative criteria while, at the same time, the prevailing mode of operation of a sizeable part of the cluster pushed the banking sector towards a catastrophe. This is not to deny the relevance of stylised phases as suggested by the adaptive-cycle model, but rather it is a call for careful consideration regarding the cases in which the use of these pre-given phases is helpful and in which cases it might be somewhat forced or even misleading. Therefore, this research supports the non-deterministic view on the evolution of clusters, and it accords with the argument of Shin and Hassink (2011) that the exact course of cluster dynamic varies from case to case.

At the empirical level, it can be concluded that Prague has never achieved a prominent position among the international financial centres, despite the rapid expansion phase of its banking sector in the late $19^{\text {th }}$ century and early $20^{\text {th }}$ century, when up to $80 \%$ of capital invested by some of the Czech banks was disbursed abroad, especially to South East Europe and Russia (Vencovský, Jindra, Novotný 1999). More recently, the suppression of Prague's banking cluster under state socialism played a role, as well as a naïve version of liberalism proclaimed in the early 1990 s by the Czech governments, resulting inter alia in a loose regulation of the (re-)emerging banking sector and subsequent dire impact on public finances and the overall image of the industry.

With regard to the impacts of the takeover on Prague's banking cluster, subsidiarisation was assessed as "inevitable" by a majority of the interviewed experts, as 
the banks were "technically bankrupt" and radical change was urgently needed in their operation. Numerous benefits were identified, such as the enhancement of the general creditworthiness of the banking sector and an introduction of new managerial and organisational structures and procedures including quality riskmanagement. On the other hand, the following major costs of subsidiarisation were reported: transfer of dividends out of the country and reassignment of some of the most profitable banking services (such as corporate banking) directly to parent banks.

Importantly, in the phase of subsidiarisation, it was not the presupposed flexibility of clustered firms (i.e. banks) or of the cluster per se that facilitated the profound transformation of the cluster at the turn of the millennium; instead, it was the opposite, namely the lack of internal adaptivity of the cluster that led an external actor - the Czech government - to invoke external drivers that would orchestrate the profound transformation of the cluster. Consequently, the cluster's recovery from its decline was realised by the external drivers, which is mostly attributable to the specific position of the banking industry in modern economies, and therefore such state-assisted transformation is less likely for clusters in other industries.

Despite the fact that one would intuitively expect that the arrival of the global economic crisis in Czechia would have induced important changes, no profound changes were identified in Prague's banking cluster during the crisis. This was the result of clearing the balance sheets of the banks during their privatisation process, and of the fact that Czech subsidiaries were not involved in trading with obscure financial derivatives. However, in contrast to major financial centres in which banking or even the whole financial cluster can adapt via re-specialisation (such as on insurance in the case of Munich, or by expansion to Central and Eastern Europe in the case of Vienna, see Zademach, Musil 2014), the banking clusters in lower-tier financial centres have much more limited space for such adaptation, as they provide predominately basic services for a particular national market.

Therefore, the analysis of the banking cluster in Prague shows that at least some of these centres are to a certain extent shielded from global competition and, consequently, are less prone to vulnerabilities stemming from external shocks, which only indirectly affect them. Likewise, as a consequence of this predominant orientation towards national markets, the banking cluster in Prague is (at least under the current operational model of the banking sector) to a certain extent "irreplaceable". As a result, banking clusters in some lower-tier centres (such as Prague) can actually function as a form of safe-haven for nested foreign capital. On the other hand, the opportunities for expansion of "subsidiarised" banking clusters are limited to the evolution of the national market, while the scope for expansion abroad is severely restricted, as parent banks are already serving foreign markets either by themselves or via another subsidiary bank. 
Consequently, further research into lower-tier financial centres is needed to see whether these financial centres would exhibit a lower tendency to fluctuate in size and in specialisation of the banking sector than the higher-order financial centres. It should be emphasised that such an expectation has been derived specifically for the banking sector due to its idiosyncratic features mentioned above. In particular, a comparative analysis of the evolution of third- or fourth-tier financial centres with higher-ranking centres is needed.

Therefore, while the banking and financial sector sits firmly at the heart of economic activities, the study of this vital sector remains (despite a recent upsurge of interest) on the periphery of research, at least within economic geography. This is even more so in the case of the former state socialism countries, and accordingly this paper seeks to stimulate further research on this challenging topic.

\section{References}

BÁRTA, V., SINGER, M. (2006): The Banking Sector after 15 Years of Restructuring: Czech Experience and Lessons. Bank for International Settlements, 28, 1, 203-212.

BOSCHMA, R., LEDDER, F. (2010): The Evolution of the Banking Cluster of Amsterdam 1850-1993: A Survival Analysis. In: Fornahl, D., Henn, S., Menzel, M.P. (eds.): Emerging Clusters: Theoretical, Empirical and Political Perspectives on the Initial Stage of Cluster Evolution. Edward Edgar, Cheltenham, 191-213.

BOSCHMA, R., FORNAHL, D. (2011): Cluster evolution and a roadmap for future research. Regional Studies, 45, 10, 1295-1298.

BROWN, E., DERUDDER, B., PARNREITER, CH. et al. (2010): World City Network and Global Commodity Chains: Towards a World Systems' Integration. Global Networks, 10, 1, 12-34.

CASSIS, Y. (2010): Capitals of Capital: The Rise and Fall of International Financial Centres 1780-2009. Cambridge University Press, Cambridge.

CORPATAUX, J., CREVOISIER, O., THEURILLAT, T. (2009): The Expansion of the Finance Industry and its Impact on the Economy: A Territorial Approach Based on Swiss Pension Funds. Economic Geography, 85, 3, 313-334.

CZECH NATIONAL BANK (1994-2013): Annual Reports of the Czech National Bank, http://www. cnb.cz/en/about_cnb/performance/annual_reports/index.html (13.4.2013).

CZECH NATIONAL BANK (1996-2005): Banking Supervision in the Czech Republic, http://www. cnb.cz/en/supervision_financial_market/aggregate_information_financial_sector/archive/ index.html (13.4.2013).

CZECH NATIONAL BANK (2006-2014): Financial Market Supervision Reports, http://www. cnb.cz/en/supervision_financial_market/aggregate_information_financial_sector/financial_market_supervision_reports/index.html (15.9.2015).

CZECH NATIONAL BANK (2013a): Database ARAD - Time Series System, http://www.cnb.cz/ docs/ARADY/HTML/index_en.htm (2.9. 2013).

CZECH NATIONAL BANK (2013b): Regulated Institutions and Registered Financial Market Entities Lists, https://apl.cnb.cz/apljerrsdad/JERRS.WEB07.INTRO_PAGE?p_lang=en (19.4.2013).

CZECH STATISTICAL OFFICE (2015a): GDP, National Accounts, http://www.czso.cz/eng/redakce. nsf/i/gdp_national_accounts_ekon (28.9.2015). 
CZECH STATISTICAL OFFICE (2015b): Labour Market in Czech Republic 1993-2014, https:// vdb2.czso.cz/vdbvo2/faces/index.jsf?page=statistiky (15.9.2015).

DRAHOKOUPIL, J., MYANT, M. (2010): Varieties of Capitalism, Varieties of Vulnerabilities: Financial Crisis and its Impact on Welfare States in Eastern Europe and the Commonwealth of Independent States. Historical Social Research, 35, 2, 266-295.

ENGELEN, E. (2007): "Amsterdammed”? The Uncertain Future of a Financial Centre. Environment and Planning A, 39, 6, 1306-1324.

ENGELEN, E., GROTE, M.H. (2009): Stock Exchange Virtualisation and the Decline of SecondTier Financial Centres -The Cases of Amsterdam and Frankfurt. Journal of Economic Geography, 9, 5, 679-696.

FAULCONBRIDGE, J.R., ENGELEN, E., HOYLER, M. et al. (2007): Analysing the Changing Landscape of European Financial Centres: The Role of Financial Products and the Case of Amsterdam. Growth and Change, 38, 2, 279-303.

FLORIDA, R. (2010): New Global Financial Order. The Atlantic, 13 October, http://www.theatlantic.com/business/archive/2010/10/new-global-financial-order/64493/ (29.5.2013).

GÁL, Z. (2015): Development of International Financial Centres in Central and Eastern Europe during Transition and Crisis: The Case of Budapest. Studia regionalne i lokalne, 60, 2, 53-80.

GROTE, M.H. (2008): Foreign Banks Attraction to the Financial Centre Frankfurt - An Inverted 'U'-shaped Relationship. Journal of Economic Geography, 8, 2, 239-258.

HRNČÍř, M. (1994): Reform of the Banking Sector in the Czech Republic. In: Bonin, J.P., Szekely, P. (eds.): The Development and Reform of Financial Systems in Central and Eastern Europe. Edward Edgar, Aldershot, 221-256.

JEŽEK, T. (2013): V české vládě se nikdy nevedly řeči o zhasnutí. Hospodářské noviny, 25, March, 10.

KARREMAN, B. (2009): Financial Geographies and Emerging Markets in Europe. Tijdschrift voor Economische en Sociale Geografie, 100, 2, 260-266.

KLEIN, M. (2012): More than the Money: A Geographical Perspective of the Transformation of the Czech Banking Sector. Seminar paper, Charles University in Prague, Dartmouth College, Prague.

LUM, S. (2013): The New Global Financial Order: Three Perspectives on Investing. CFA Institute, 12 February, http://blogs.cfainstitute.org/investor/2013/02/11/the-new-global-financialorder-threeperspectives-on-investing/ (20.2.2013).

MARTIN, R., BERNDT, C., KLAGGE, B. et al. (2005): Spatial Proximity Effects and Regional Equity Gaps in the Venture Capital Market: Evidence from Germany and the United Kingdom. Environment and Planning A, 37, 7, 1207-1231.

MARTIN, R., SUNLEY, P. (2011): Conceptualising Cluster Evolution: Beyond the Life Cycle Model? Regional Studies, 45, 10, 1299-1318.

MERVART, J. (1998): České banky v kontextu světového vývoje. Lidové noviny, Praha.

MENZEL, M.P., FORNAHL, D. (2010): Cluster Life Cycles - Dimensions and Rationales of Cluster Evolution. Industrial and Corporate Change, 19, 1, 205-238.

PORTER, M. (2003): The Economic Performance of Regions. Regional Studies, 37, 6, 549-578.

SHIN, D., HASSINK, R. (2011): Cluster Life Cycles: The Case of the Shipbuilding Industry Cluster in South Korea. Regional Studies, 45, 10, 1387-1402.

SMITH, A., SWAIN, A. (2010): The Global Economic Crisis, Eastern Europe, and the Former Soviet Union: Models of Development and the Contradictions of Internationalisation. Euroasian Geography and Economics, 51, 1, 1-34.

TAYLOR, P.J., WALKER, D.R.F., CATALANO, G. et al. (2002): Diversity and Power in the World City Network. Cities, 19, 4, 231-241. 
VENCOVSKÝ, F., JINDRA, Z., NOVOTNÝ, J. et al. (1999): Dějiny bankovnictví v českých zemích. Bankovní institut, Praha.

WEILL, L. (2003): Banking Efficiency in Transition Economies. The Role of Foreign Ownership. Economies of Transition, 11, 3, 569-592.

WÓJCIK, D. (2009): Financial Centre Bias in Primary Equity Markets. Cambridge Journal of Regions, Economy and Society, 2, 2, 193-209.

ZADEMACH, H.M., MUSIL, R. (2014): Global Integration Along Historic Pathways: Vienna and Munich in the Changing Financial Geography of Europe. European Urban and Regional Studies, 21, 4, 463-483.

\section{Statistical materials:}

Obchodní banky a pojištovny v České republice. Česká národní banka, Praha 1994.

Bankovní a finanční sektor v České republice. Česká národní banka, Praha 1996-1997.

Zpráva o činnosti bankovního dohledu v České republice. Česká národní banka, Praha 1999.

Statistická ročenka ČSFR. Český statistický úřad, Praha 1991.

Obchodní rejstř́k a sbírka listin. Ministerstvo spravedlnosti České republiky, Praha 2013, https://or.justice.cz/ias/ui/rejstrik (22.4.2013).

\section{SHRNUTí}

\section{Převzetí pražského bankovního klastru zahraničními finančními skupinami v evoluční perspektivě}

Cílem článku je identifikovat hlavní faktory ovlivňující vývoj bankovního klastru v Praze za posledních cca 200 let. Konceptuálně práce vychází jak z literatury o mezinárodních finančních centrech, tak i z nově vytvořeného modelu vývoje klastrů, tj. modelu adaptivního cyklu. Oproti dosud dominantnímu modelu vývoje klastrů, kterým je model životního cyklu, model adaptivního cyklu poskytuje větší prostor pro roli vnějších vlivů a aktérů. Aplikace konceptu klastru na bankovnictví, která je v odborné literatuře dosud spíše výjimečná, se ukázala jako vhodná, nebot bankovnictví je oborem, který si díky svým významným specifikům udržuje zřetelnou identitu i v dlouhodobé perspektivě, což usnadňuje identifikaci klíčových faktorů vývoje. Analýza ukázala, že vývoj bankovního klastru v Praze byl - vedle víceméně neustálých postupných proměn - hnán především několika významými událostmi externí povahy (národní obrození, vznik Československa, nastolení komunistického režimu po druhé světové válce, naopak jeho pád v roce 1989). Zvláštní pozornost je věnována zatím poslední fázi vývoje bankovního klastru v Praze, kdy byly na počátku nového tisíciletí klíčové banky převzaty zahraničními bankovními skupinami, a české banky se tak staly jejich pobočkami. Pozitiva i negativa převzetí rozhodující části českých bank byla analyzována na základě polostrukturovaných rozhovorů s experty komerčních bank, centrální banky i řady nebankovních finančních institucí. Z výzkumu vyplynulo, že i přes nemalé náklady a rizika spojené s převzetím českých bank zahraničními skupinami převažují výhody, z nichž některé se poněkud překvapivě projevily v době globální ekonomické a finanční krize. Dopady této krize na český bankovní klastr byly proto až neočekávaně malé, což dokládá i skutečnost, že si pražský bankovní klastr dokázal jako celek udržet ziskovost i během této krize. Samotné převzetí experti považovali za nevyhnutelné, nebot' banky byly „technicky zbankrotované" a bylo nutné zajistit radikální změnu jejich fungování. Za hlavní výhody 
vyplývající z jejich převzetí experti považovali celkové zvýšení důvěryhodnosti v bankovní soustavu, mj. dané změnami manažerských postupů a organizačními změnami, které vedly zejména k hluboké proměně řízení rizik. Z hlediska klientů (fyzických i právnických osob) byla zavedena řada nových služeb a zvýšena jejich spolehlivost. Naopak, za hlavní rizika experti považovali odliv zisků ve formě dividend a realokaci některých nejziskovějších bankovních služeb př́mo do zahraničních centrál.

Z konceptuálního pohledu tato studie potvrdila hlavní argument adaptivního modelu vývoje klastrů, tj. že je nepravděpodobné, že by vývoj klastrů byl hnán po celé období nějakým základním podmiňujícím faktorem, jako je např. úroveň heterogenity znalostní základny členů klastru. Místo toho byly v různých fázích vývoje pražského bankovního klastru identifikovány různé faktory, které navíc byly často externí povahy. Do značné míry výjimečnou situací, vyvolanou specifickým významem bankovnictví pro celou ekonomiku, byla skutečnost, že problémy českého bankovnictví nebyly vyřešeny díky aktivitě členů klastru, tj. samotných komerčních bank, ale byly řešeny rozhodnutím vnějšího aktéra - české vlády - přijaté na základě podnětu bankovního regulátora. Tato státem indukovaná transformace je proto v případě jiných klastrů jen málo pravděpodobná.

Další výzkum finančních center nižšího řádu by mohl ukázat, zda tato finanční centra vykazují ve srovnání s centry vyšších řádů větší stabilitu a menší specializaci danou jejich převážnou orientací na domácí trh a tím jejich částečným odstíněním od problémů spojených s globalizací finančních toků a jejich problematickou regulací. Následný výzkum by také mohl ukázat, jaké dopady nejen na centra třetího řádu, ale i na celý bankovní systém budou mít dvě velmi protichůdné tendence probíhající v současném bankovnictví. První tendencí je klesající potřeba prostorové blízkosti daná stále rozvinutějšími bankovními komunikačními technologiemi, druhou pak zvýšená potřeba osobních kontaktů v případě poskytování nových znalostně intenzivních bankovních služeb.

Obr. 1 Podíl nesplácených úvěrů na celkovém objemu poskytnutých úvěrů. V legendě (zleva doprava): ztrátové úvěry, pochybné úvěry, nestandardní úvěry, sledované úvěry.

Obr. 2 Vývoj struktury poskytnutých úvěrů. V legendě (shora dolů): nerezidenti, neziskové organizce, domácnosti, vládní sektor, finanční instituce, nefinanční instituce.

\section{ACKNOWLEDGEMENT}

This work was supported by the European Science Foundation grant provided by the Czech Science Foundation No. CRP/11/E025 Cluster Life Cycles - the role of actors, network and institutions in emergence, growth, decline and rejuvenation of clusters. The authors would like to thank to Olivier Crevoisier, both reviewers and the Editor for their constructive feedback, to Michael Klein for performing one of the interviews and to our interviewees for sharing their insights. 